\title{
PENGARUH PERILAKU BUDAYA GENERASI MILLENIIAL MENGHADAPI REVOLUSI INDUSTRI TERHADAP RUANG HUNIAN PRIBADI DENGAN STUDI KASUS ‘ONE ROOM LIVING’ MAHASISWA
}

\author{
Dwi Sulistyawati ${ }^{1}$ \\ Imam Santosa \\ Fakultas Seni Rupa dan Desain, Institut Teknologi Bandung \\ Soeli1988@gmail.com
}

\begin{abstract}
ABSTRAK
Setiap individu atau pribadi sedang menghadapi konflik ketika menghadapi Revolusi Industri yang sedang berkembang saat ini, yaitu antara Das Sein (apa yang kenyatanya terjadi atau realita) dan Das Sollen (apa yang seharusnya terjadi atau yang diharapkan) dalam memahami nilai budaya nasional akibat berubahnya fasilitas berupa seting fisik, dimana pribadi atau individu tersebut melakukan aktivitas dan berperilaku pada hunian ruang ataupun seting fisik dapat merubah perilaku penggunanya. Demikian halnya Mahasiswa sebagai individu atau pribadi pada posisi generasi millennial yang merupakan generasi pada usia produktif yang termasuk lahir pada tahun 1982-2004 (Howe \& Strauss) hadir pada pada masa kini. Karena Perkembangan budaya masa kini khususnya bagi mahasiswa generasi Millennial bisa membawa dampak yang cukup signifikan. Sehingga memiliki fenomena budaya yang terjadi dan dialami pada fase kehidupan mereka dalam mempengaruhi kualitas hidup dan lingkungannya dimana dia berada, oleh sebab itu penelitian yang bertujuan untuk mengetahui pola perilaku beraktivitas mahasiswa sebagai pengguna dari latar belakang generasi Millenial dalam perananannya sebagai individu atau pribadi dalam merespon ruang berupa One Room Living ini menggunakan metode Triangulasi dengan sumber, yaitu membandingkan dan mengecek balik derajat kepercayaan suatu informasi yang diperoleh melalui waktu dan alat yang berbeda dalam penelitian kualitatif. Ada dampak kemajuan teknologi pada revolusi industri yang berkembang dan menyebabkan perubahan karakter dan perilaku, karena dimanjakan oleh teknologi maka generasi Millennial mempunyai karakter yang instan, melakukan beberapa kegiatan dalam waktu bersamaan/multi talent. Dengan adanya perubahan karakter dan perilaku masyarakat pada generasi Millennial, maka dibutuhkan sarana dan prasarana sebagai wadah beraktifitas di ruang hunian yang compact dan multi fungsi.

Kata kunci: Generasi Millennial, Pola Perilaku, seting fisik
\end{abstract}

\begin{abstract}
Every individual or person is facing conflict when facing the Industrial Revolution that is developing at the moment, namely between Das Sein (what is true or reality) and Das Sollen (what should or should be expected) in understanding national cultural values due to changing facilities in the form of physical settings, where the individual or individual conducts activities and behaves in space occupancy or physical settings can change the behavior of its users. Likewise, students as individuals or individuals in the position of the millennial generation who are the generation of productive age, including those born in 1982-2004 (Howe \& Strauss) who are present at present, can have a significant impact so that they have cultural phenomena occurring and experienced in the phase of their lives in influencing the quality of life and the environment in which he is, therefore research that aims to determine the pattern of student activity behavior as users of the Millennial generation background in their role as individuals or individuals in responding to the space in the form of "One Room Living" uses Triangulation method with sources, namely comparing and checking back the degree of trust of information obtained through different time and tools in qualitative research. There is an impact of technological progress on the industrial revolution that develops and causes changes in character and behavior, because it is spoiled by technology, the Millennial generation has instant characters, performs multiple activities at the same time / multi talent. With the change in the character and behavior of the people in the Millennial generation, facilities and infrastructure are needed as a place for activities in a "compact" and multi-functional residential space.
\end{abstract}
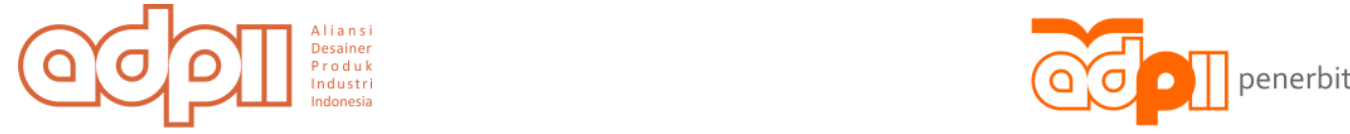
Keywords: Millennial Generation, Behavioral Patern, physical setting

\section{PENDAHULUAN}

Sejarah revolusi industri dimulai dari industri 1.0, 2.0, 3.0, hingga industri 4.0. Fase industri merupakan real change dari perubahan yang ada. Industri 1.0 ditandai dengan mekanisasi produksi untuk menunjang efektifitas dan efisiensi aktivitas manusia, industri 2.0 dicirikan oleh produksi massal dan standarisasi mutu, industri 3.0 ditandai dengan penyesuaian massal dan fleksibilitas manufaktur berbasis otomasi dan robot. Industri 4.0 selanjutnya hadir menggantikan industri 3.0 yang ditandai dengan cyber fisik dan kolaborasi manufaktur [1]. Arus globalisasi sudah tidak terbendung masuk ke Indonesia. Disertai dengan perkembangan teknologi yang semakin canggih, dunia kini memasuki era revolusi industri 4.0, yakni menekankan pada pola digital economy, artificial intelligence, big data, robotic, dan lain sebagainya atau dikenal dengan fenomena disruptive innovation (Sumber daya ristek dikti,2018)

Setiap individu atau seseorang sedang menghadapi konflik ketika menghadapi Revolusi Industri yang sedang berkembang saat ini, yaitu antara Das Sein (apa yang kenyatanya terjadi atau realita) dan Das Sollen (apa yang seharusnya terjadi atau yang diharapkan) dalam memahami nilai budaya nasional akibat berubahnya fasilitas berupa seting fisik, dimana pribadi atau individu tersebut melakukan aktivitas dan berperilaku pada seting fisik (ruang) atau seting fisik (ruang) dapat mempengaruhi aktivitas perilaku penggunanya.

Pentingnya redefinsi bahwa kepentingan revolusi industri adalah sebagai kepentingan mempermudah keinginan (wants) manusia dalam memenuhi kebutuhannya (needs). Sehingga makna tesebut dapat digerakkan oleh aturan dan petunjuk pelaksanaan (rule driven) dan dapat menyentuh permasalahan masyarakat yang bervariasi pada tingkat akar rumput (grass root). Hadirnya industriaslisi bukan memarginalisasi manusia sebagai pengggerak kegiatan produksi, tapi justru mengedepankan peran manusia sebagai subyek yang mampu memberikan jalan kemudahan / keterjangkaun dari hasil industri tersebut. [2]

Revolusi industri yang sedang berkembang saat ini juga memunculkan ekonomi berbasis teknologi atau yang lebih dikenal dengan ekonomi digital. Pada era ini potensi Indonesia dapat memberi kontribusi yang lebih besar kepada perkembangan dunia. Indonesia merupakan empat negara besar dengan jumlah penduduk sekitar 260 juta penduduk yang terdiri dari multikultural dan terbagi pada daerah kepulauan yang terpisah jarak, ruang dan waktu. Jumlah penduduk yang besar ini dan mayoritas penduduknya ada pada rentang usia 15-64 tahun, dimana usia tersebut disebut usia produktif (Indonesia-invesment, 2017). Strauss dan Howe mendefinisikan generasi sebagai agregat dari semua orang yang lahir selama rentang waktu sekitar dua puluh tahun atau sekitar panjang satu fase dari masa kanak-kanak, dewasa muda, usia pertengahan dan usia tua. Selain itu terdapat tiga kriteria yang harus dimiliki oleh sebuah generasi yaitu usia lokasi dalam sejarah, kepercayaan dan perilaku yang sama, serta keanggotaan periode yang sama. Kriteria pertama maksudnya adalah generasi yang sama akan mengalami peristiwa sejarah penting dan tren sosial bersamaan. Hal ini akan menyebabkan sebuah generasi akan berbagi beberapa kepercayaan dan perilaku yang sama. Kriteria terakhir artinya sebuah generasi akan mengidentifikasi dirinya sebagai kelompok yang berbeda dibanding generasi lainnya. [3]

Generasi Millennial (alias NextGen, Gen- $Y, C$ Generation, M Generation, dan Echo Boomers) yang lahir dalam kurun waktu dimulainya tahun 1982-2004 adalah generasi terbesar sebagai masyarakat penggemar digital (digital narative), multitaskers. Secara global, Milenium didefinisikan sebagai generasi yang tumbuh di era baru globalisasi, teknologi komunikasi dan konektivitas nirkabel. Mereka hidup di zaman dengan keragaman yang belum pernah terjadi sebelumnya dan paparan terhadap budaya lain. Mereka tumbuh dengan cepat, terlalu cepat, dan generasi ini sangat percaya diri.

Tabel 1. Periode Milleniial [4]

\begin{tabular}{|l|l|c|l|c|c|}
\hline \multicolumn{5}{|c|}{ Millennial Saeculum (age 74) } & \\
\hline Baby Boom Generation & Prophet (Idealist) & $1943-1960(17)^{\text {[Sa] }}$ & 1st Turning: High: Superpower America & 1946-1964 (18) \\
\hline 13th Generation (Generation X) & Nomad (Reactive) & $1961-1981$ (20) & 2nd Turning: Awakening: Consciousness Revolution & 1964-1984 (20) \\
\hline Millennial Generation (Generation Y) & Hero (Civic) & $1982-2004(22)$ & 3rd Turning: Unraveling: Culture Wars, Postmodernism & 1984-2008 (24) \\
\hline Homeland Generation (Generation Z) & Artist (Adaptive) & 2005-present (age 12) & 4th Turning: Crisis: Great Recession/War on Terror & 2008- \\
\hline
\end{tabular}
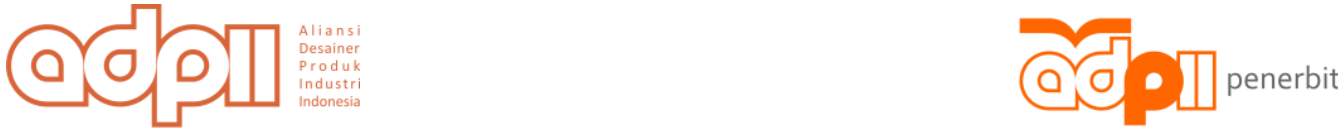
Akibat hidup di zaman dengan keragaman yang belum pernah terjadi sebelumnya dan dengan paparan terhadap budaya lain, maka terjadilah perubahan perilaku pada generasi Millenial tersebut. Perubahan perilaku tersebut dapat berdampak terhadap fasilitas sarana dan prasarana dalam merespon seting fisik individu atau pribadi, demikian pula sebaliknya. Banyak penelitian berkait dengan generasi Millennial, tetapi budaya generasi millennial yang dikaitkan dengan aktivitas berperilaku dalam merespon seting fisiknya masih belum tersentuh.

Perilaku mengenal berbagai tingkatan, yaitu:

1. Perilaku sederhana seperti refleks dan stereotip dan perilaku kompleks seperti perilaku sosial manusia, yang juga dapat melibatkan proses mental biologis yang lebih tinggi.

2. Perilaku bervariasi klasifikasi : kognitif, afektif dan psikomotorik yang menunjuk pada sifat rasional, emosional dan gerakan fisik dalam berperilaku.

3. Perilaku bisa disadari dan juga tidak di sadari.

Perilaku manusia akan mempengaruhi dan membentuk setting fisik lingkungannya [1]. Pengaruh lingkungan terhadap tingkah laku dapat dikelompokkan menjadi 3 yaitu :

1. Environmental Determinism, menyatakan bahwa lingkungan menentukan tingkah laku masyarakat di tempat tersebut.

2. Enviromental Posibilism, menyatakan bahwa lingkungan fisik dapat memberikan kesempatan atau hambatan terhadap tingkah laku masyarakat.

3. Enviromental Probabilism, menyatakan bahwa lingkungan memberikan pilihan-pilihan yang berbeda bagi tingkah laku masyarakat.

Teori diatas bisa bergeser ketika ada perubahan aktivitas berperilaku manusia saat ini dari dampak Revolusi Industri yang berkembang dan dapat menyebabkan perubahan keberadaan bangunan sebagai sarana lingkungan fisik seperti hunian Residensial akibat adanya (Go-food,you-tub, media-sosial dll), Pendidikan akibat adanya (artificial Intellegence), Pertokoan akibat adanya (shoping on-line), Perkantoran (co-working), dan lain-lain. Fenomena ini yang kemudian menarik untuk di teliti lebih lanjut, karena teori tentang kegunaan atau fungsi ruang sekarang ini semakin banyak dan terus meluas, dalam berbagai bentuk formulasi, kekurang cukupan ruang personal atau jarak spasial yang akan menimbulkan ketidaknyamanan (discomfort), kurang terlindung (a lack of protection), membangkitkan siaga tubuh berlebihan (arousal), menimbulkan stres (stress), kelebihan beban stimulus (stimulus overload), kecemasan (anxiety), ketidakseimbangan (disequilibrium), kurang komunikasi dan membatasi kebebasan pribadi seseorang.

\section{METODE}

Metode yang digunakan adalah metode Triangulasi dengan sumber, yaitu membandingkan dan mengecek balik derajat kepercayaan suatu informasi yang diperoleh melalui waktu dan alat yang berbeda dalam penelitian kualitatif, untuk membuktikan Informasi tentang dampak kemajuan teknologi pada era Revolusi Industri 4.0 dapat menyebabkan perubahan karakter dan perilaku bagi generasi Millennial, yang kemudian akan dikaji bagaimana perubahan karakter dan perilaku mahasiswa sebagai pelaku generasi Millennial dalam merespon ruang hunian individunya yaitu One room Living.

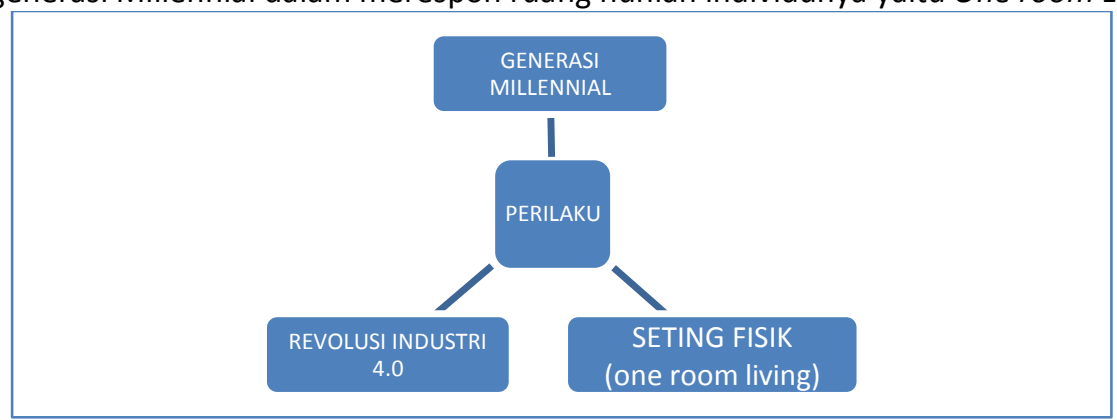

Gambar 1. Bagan Pengaruh Perilaku (Analisis Pribadi,2018)

Penelitian ini juga bersifat Kajian atau studi eksplorasi metodologi, penyajiannya deskripsi kwalitatif, yaitu Menjelaskan latar belakang mahasiswa sebagai pelaku yang mewakili generasi Millennial kemudian merekam/mengumpulkan temuan aktivitas yang terjadi dalam ruang hunian One Room Living yang dihuni oleh mahasiswa tersebut dan menjelaskan temuan aktivitas rata-rata yang terjadi baik
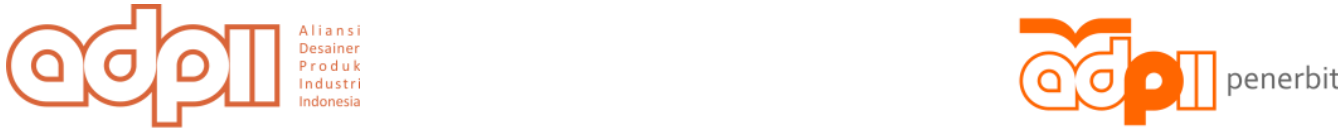


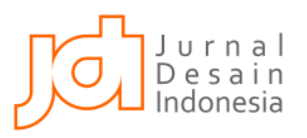

sehari-hari maupun akhir pekan dengan cara mengumpulkan data dengan cara mewawancarai, , mengamati, mencatat, mengolah dan mendeskripsikan hasil penelitian. Pendekatan deskriptif dilakukan untuk menggambarkan dan menginterpretasikan obyek studi melalui latar belakang, aktivitas dan hunian one living room mahasiswa tersebut. Yang kemudian hasil temuan tersebut diharapkan dapat memberikan arahan dalam membuat prototipe pola perilaku dan seting fisik yang dapat memberikan kualitas hidup bagi generasi millennial yang di wakilinya. Teknik observasi sistematis ini merekam latar belakang, aktivitas dan hunian One Room Living 35 mahasiswa yang mewakili generasi Millennial dalam jangka waktu yang sudah ditentukan. Ada 4 unsur yang berkaitan dalam proses analisis yaitu: Pelaku, Aktifitas, Seting Fisik dan Waktu, adapun data dan Analisa yang diperoleh adalah sebagai berikut:

1. Pelaku

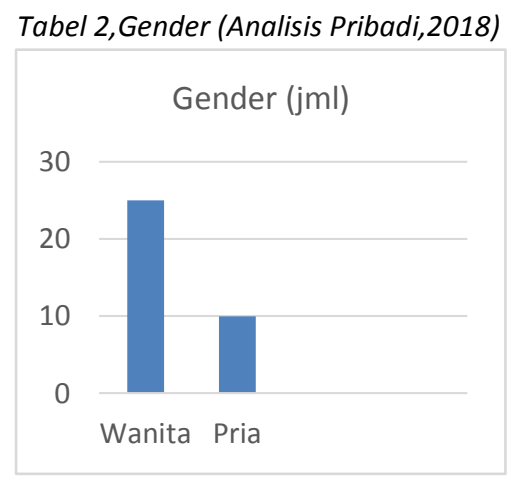

Tabel 3,Tahun Kelahiran (Analisis Pribadi,2018)

Tabel 4, Jenis Media Sosial (Analisis Pribadi,2018) Tahun Kelahiran (Jml)
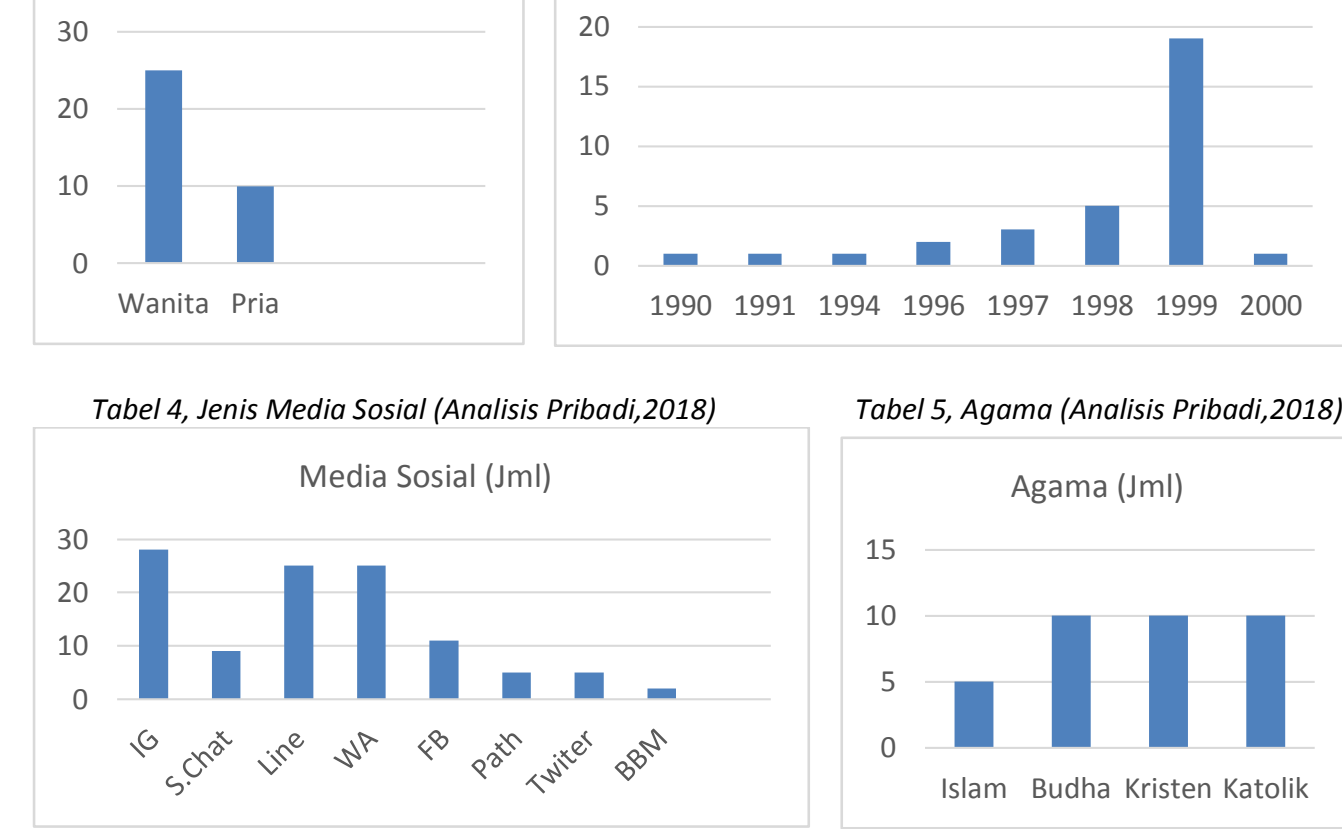

Tabel 5, Agama (Analisis Pribadi,2018)

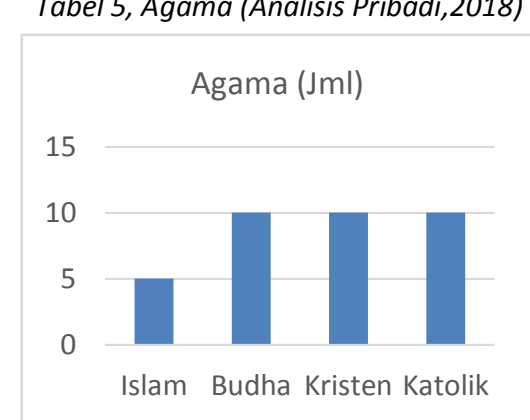

Tabel 6, Etnis (Analisis Pribadi,2018)

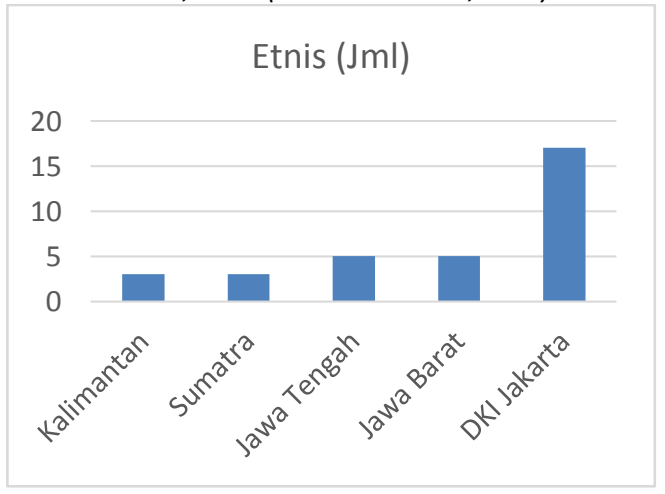

Tabel 7, Hobi (Analisis Pribadi,2018)

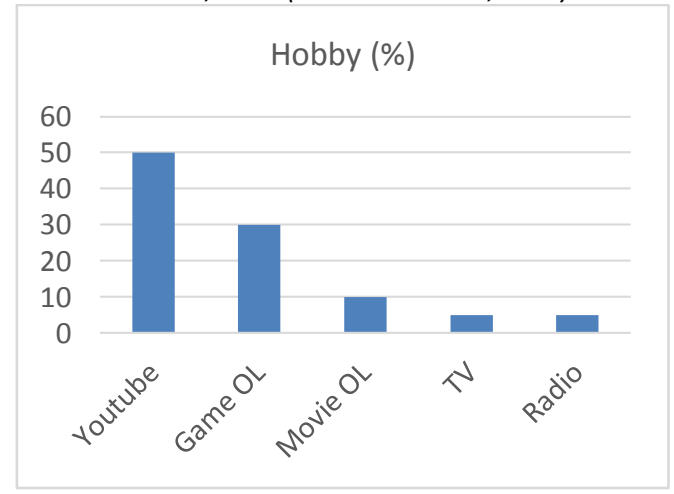

2. Aktivitas

Tabel 8, Gender (Analisis Pribadi,2018)

Tabel 9, Makan (Analisis Pribadi,2018)

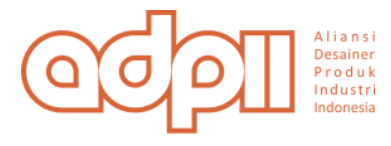




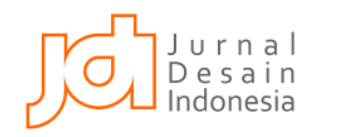

Jurnal Desain Indonesia Volume 01, nomor 01 - Aliansi Desainer Produk Industri Indonesia
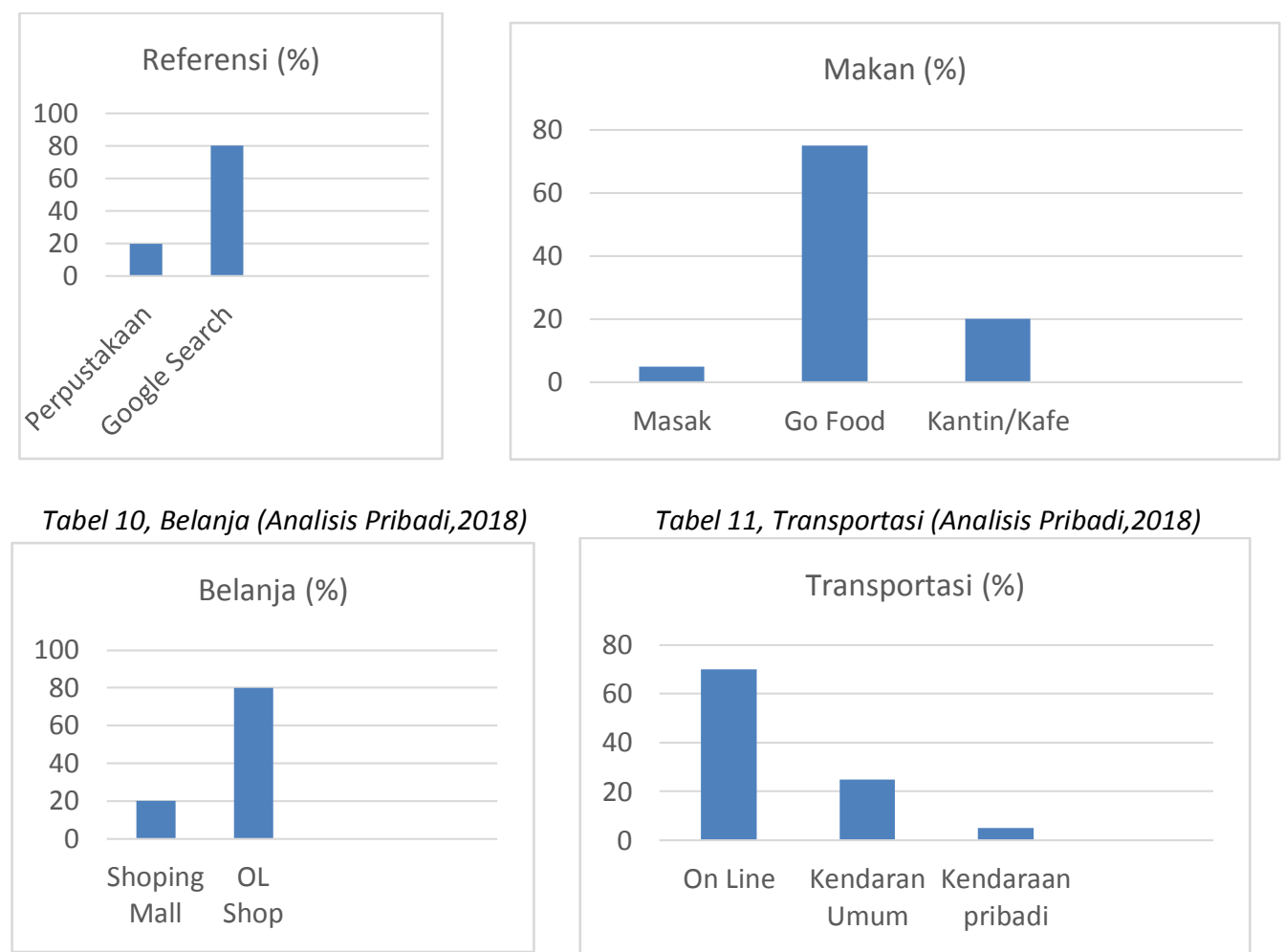

Tabel 11, Transportasi (Analisis Pribadi,2018)

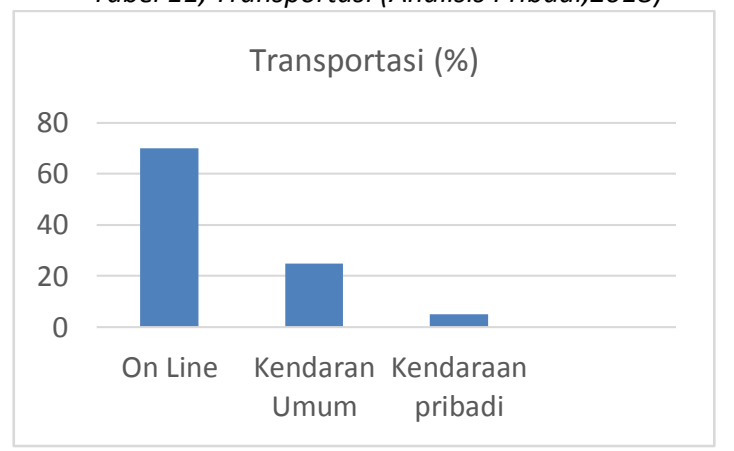

Tabel 12, Sosialisasi (Analisis Pribadi,2018)

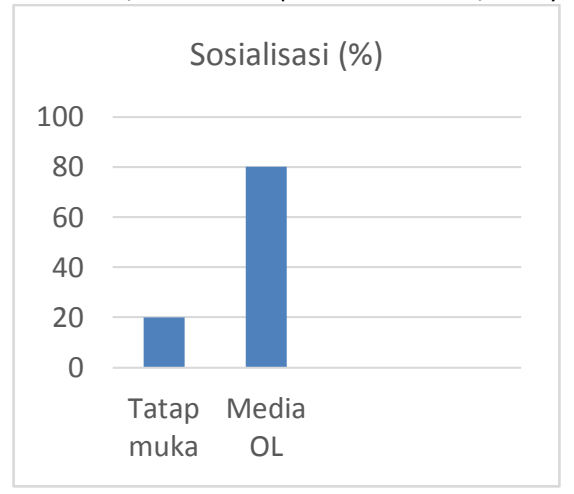

\section{Ruang/fisik}

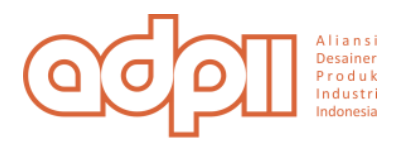




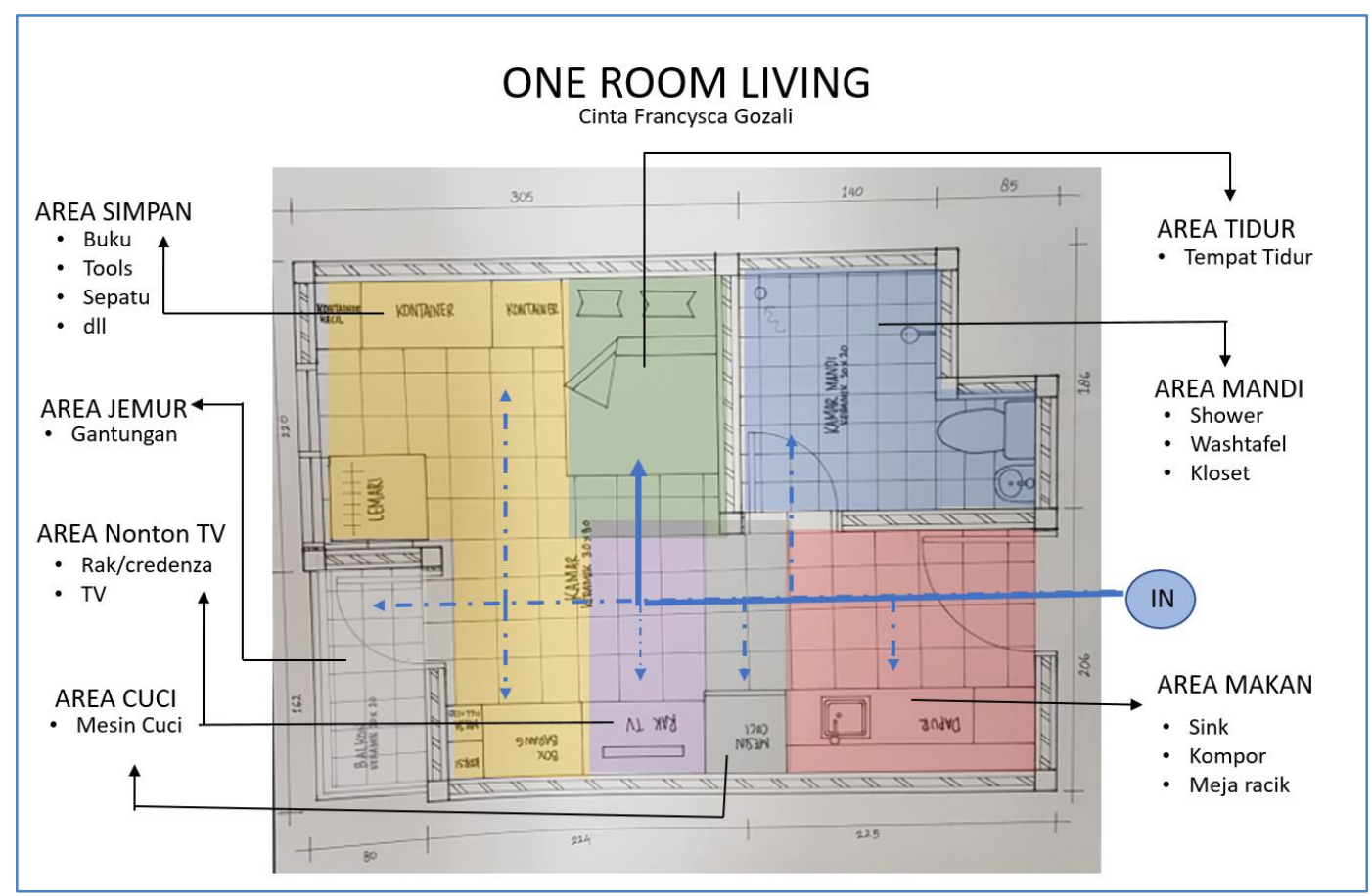

\section{Gambar 2. Seting Fisik (Analisis Pribadi,2018)}

4. Waktu

Pengamatan yang dilakukan pada aktifitas pengguna dan seting fisiknya pada saat Weekdaysdan Weekend selama 24 jam direkam berdasarkan hasil kuesioner, wawancara dan melihat langsung di waktu-waktu tertentu. Data dan analisis yang dihasilkan diambil per rata-rata adalah sebagai berikut:

Tabel 13, Penggunaan Waktu (Analisis Pribadi,2018)

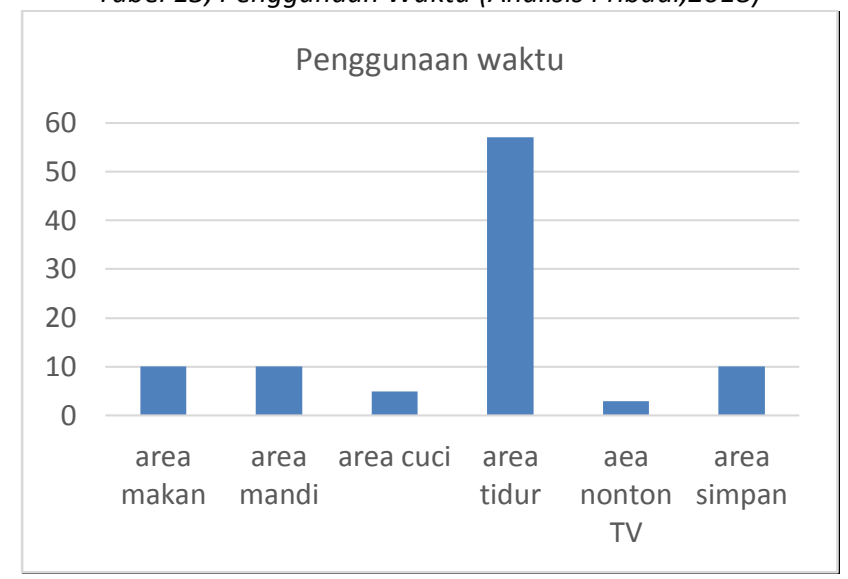

Penggunaan area Tidur menempati posisi waktu tertinggi karena hampir disetiap kegiatan selain tidur dilakukan diarea ini dengan menggunakan HandPhone (Smartphone) atau Laptop seperti: belajar (Ebook, google search), bersosialisasi (Media sosial), Hobi (games), nonton (Youtube), dll. Sedangkan Penggunaan waktu terendah adalah pada area menonton TV karena waktu mereka banyak digunakan pada kegiatan yang bersifat On-Line.

\section{DISKUSI}

Dilihat dari hasil analisis diatas menujukan bahwa

1. Menyatakan bahwa generasi Millennial yang diwakili oleh Mahasiswa dari latar belakang yang beragam (tahun kelahiran, gender, religion, etnis, hobi dan sosialisasi) memiliki ketergantungan yang tinggi pada digital khususnya Smart Phone, sehingga menguatkan pendapat bahwa generasi millennial adalah generasi digital yang narrative.
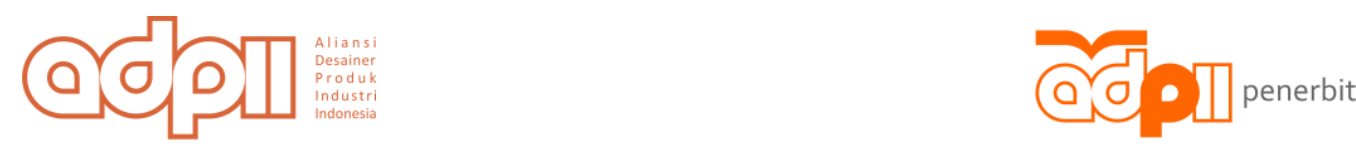
2. Aktivitas berperilaku generasi Millennial mahasiswa universitas Tarumangara sehari-hari seperti: Belajar, makan, transportasi, berhubungan sosial, membeli/mendapatkan berbagai macam kebutuhan (primer,skunder,tersier) kebanyakan dilakukan melalui perangkat digital dengan mengandalkan internet

Digital Ekonomi disini cukup memberi peluang manfaaat bagi generasi Millennial

3. Beberapa sarana dan prasarana yang ada pada hunian One Room Living yang ada, sudah tidak lagi dimanfaatkan secara maksimal akibat banyak aktivitas berperilaku yang dilakukan dalam waktu bersamaan dan dimudahkan dengan perangkat teknologi digital. Beberapa sarana dan prasarana yang sudah diambil alih :

- Perangkat belajar (Buku-buku referensi, alat tulis dll) digantikan google, program soft ware, dll. Oleh sebab itu artificial Intelegent sangatlah berpengaruh

- Persiapan Makan (Pantry area) seperti perangkat memasak sudah tidak maksimal lagi penggunaannya, karena sudah ada Go Food

- Bersosialisasi (Area duduk/tamu) banyak menggunakan Media Sosial (IG, Youtube, WA, FB, Line dII) oleh sebab itu ada peribahasa "Mendekatkan yang jauh, menjauhkan yang dekat"

4. Dengan adanya aktivitas yang dilakukan bersamaan karena didukung oleh Teknologi dari pengaruh berkembangnya Revolusi Industri mengakibatkan mahasiswa sebagai generasi Millennial memiliki kecenderungan yang Multi Talent

5. Seting fisik di hunian One Room Living mahasiswa sebagai pelaku generasi Millennial penggunaannya tidak maksimal sesuai fungsinya. Sehingga memungkinkan nantinya dibuatkan suatu konsep sebagai guide lines tentang seting fisik yang bisa menunjang aktivitas berperilaku generasi tersebut menjadikannya hidup lebih baik

\section{KESIMPULAN}

Dari riset menunjukkan bagaimana dan untuk apa tujuan individu sebagai generasi millennial tersebut menggunakan ruang. Dan ini tidak merefleksikan secara langsung mengenai apa fungsi ruang itu. Hal itu lebih menunjukkan bahwa fungsi ruang / tergantung dari desain fisik dan label penamaannya saja. Ruang adalah sistem lingkungan binaan yang paling kecil. Dalam banyak kasus fungsi ruang ditentukan oleh fungsi dari sistem yang lebih besar. Fungsi ini menjadi jelas karena sebagian besar fungsi ini sesuai dengan kegiatan yang teratur berlanjut di ruangan tersebut.

Ada pengaruh yang cukup signifikan antara revolusi Industri, Generasi Millennial. Dan Seting fisik terhadap Pola Perilaku pengguna, disini menunjukan bahwa antara Das Sein (apa yang terjadi) dan Das Solen (apa yang diharapkan) bisa menjadi tidak sesuai. Seting Fisik yang ada sebagian sudah tidak lagi berfungsi secara maksimal akibat tergantikan dengan Media teknologi (SmartPhone). Hal ini mengakibatkan perubahan pola perilaku yang bisa juga berdampak positif maupun negatif. Dampak Positifnya adalah menjadikan generasi millennial ini dapat melakukan kegiatan bersamaan dalam satu waktu, sedangkan dampak negatif nya adalah tidak adanya kesimbangan (unbalanced) terhadap tubuh yang tak bergerak (Kinetis).

\section{Daftar Pustaka}

[1] A. Raoport, The Meaning of the Built Environment, The University of Arizona Press, 1990.

[2] H. Suwardana, "Revolusi Industri 4.0 Berbasis Revolusi mental," Jurnal Jati Unik, vol. Vol.1, no. No. 2, 2017.

[3] R. s. Nugroho, Pengantar Teori Generasi Strauss-Howe, Bandung: Majalah Ganesha. Kelompok Studi Sejarah Ekonomi dan politik ITB Bandung, 2016.

[4] N. \&. S. W. Howe, Millennials rising: The next great generation., New York: Vintage, 2000.
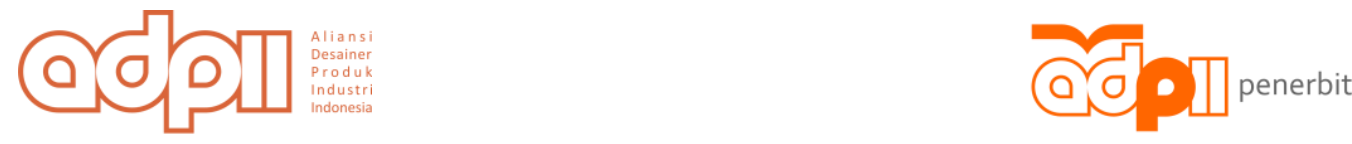